\title{
C.J. Kaunda
}

\section{THE WILDERNESS WANDERINGS: A THEO-LIMINAL PEDAGOGY FOR MIND DECOLONISATION IN AFRICAN CHRISTIANITY}

\section{ABSTRACT}

This article argues that the current economic and political underdevelopment in the majority of African countries is a symptom of a profound metaphysical and intellectual crisis in the African person's imagination and consciousness, a consequence of conceptual alienation wrought about mind colonialism. The process of decolonisation did not end with geopolitical liberation, but continues as liberation of the African mind and subjectivity. Reading this reality in light of the Exodus wilderness wanderings as theo-decolonial paradigm, the article suggests a theo-liminal pedagogy for engaging in the process of mind decolonisation.

\section{INTRODUCTION}

Emancipate yourselves from mental slavery. None but ourselves can free our minds (Bob Marley s.a.)

African nations ${ }^{1}$ are not the first to have suffered subjugation in human history. Many nations or groups of people have suffered domination

1 There is always a temptation to conceive all things "African" as essentially monolithic. Africa is an extremely variegated continent and makes it difficult in current debates on who should be considered African. Various contentions have proliferated from rejections to uncritical acceptance of the concept. In this article, I use the notion "Africa" and its adjective "African" to refer to the people of Bantu ancestry who are geographically located in sub-Saharan Africa. While, on the one hand, some scholars have argued that one cannot

Dr. C.J. Kaunda, Postdoctoral Research Fellow in Christian Spirituality at the University of South Africa, Pretoria. E-mail: pastorchammah@gmail.com. 
by powerful nations in one way or the other, and some have managed to recover. One such group was the Hebrews. They were enslaved for over 400 years in Egypt, but managed to recover and reconstitute their Hebraic subjectivity. Several questions arise: How did the Hebrew exslaves manage to recover? What did they do differently in the process of de-enslavement that African nations did not do? What was missed in the process of African decolonisation? In his book Coloniality of power in postcolonial Africa (2013a), Ndlovu-Gatsheni observes that, due to coloniality, ${ }^{2}$ the ex-colonised have

found it hard to climb on the ladder of global powers hierarchy and have thus remained at the bottom where norms and rules are routinely handed down to them from the metropolitan capitals of the industrial North.

Ndlovu-Gatsheni (2012: 423) believes that

coloniality lies at the centre of the making of the modern/colonial world of yesterday and today, where Europe and America are at the apex of global power hierarchy, and Africa is at the bottom.

Like Ndlovu-Gatsheni (2013a:1), the majority of "postcolonial neo-colonial" African scholars have accused external forces for Africa's development crisis. This has not helped the situation, often leaving the question as to whether there is something else that can be done differently in African scholarship. To what extent should Euro-America be blamed for the African dilemma?

The response to this question depends on the scholars" schools of thought: externalist or internalist. If the scholar is an externalist, the blame will be laid squarely at the feet of colonialism and imperialism, which Mazrui (1986:164) suspected to have "harmed indigenous technological

talk of African culture in the singular because of the fragmentation and diversity among African people, African scholars, on the other hand, have demonstrated that beyond such cultural fragmentations, ethnic plurality and language diversity are unambiguously in harmony and congruence within African thought systems. I acknowledge religious-cultural differences, but I also acknowledge similarities in these religious cultures and historical experiences that overwhelm the differences, turning them into strength rather than rivalry and opposition (Pobee 1979; Gyekye 1987; Phiri 1997).

2 Coloniality captures the long-established patterns of power as a consequence of colonialism, and continues to define religion, politics, cultures, mentalities, labour, relations, and knowledge construction in contemporary Africa. "In a way, as modern subjects we breathe coloniality all the time and every day" (Mignolo 2005:6). For a similar argument, cf. Ndlovu-Gatsheni 2011. 
development", ${ }^{3}$ the legacy of which continues as coloniality manifests through what Ayittey (2002:58) describes as

exploitation by avaricious multinational corporations, an unjust international economic system, inadequate flows of foreign aid, and deteriorating terms of trade.

An internalist would argue that, while external factors have played a significant role in determining the continent, internal factors are far more critical in understanding the African dilemma and how coloniality is sustained (cf. Achebe 1985; Ayittey 1992, 1998).

One internal factor is what the Kenyan scholar wa Thiongo (1986) termed "mind colonisation". Scholars and Africanists such as Fanon (1952, 1961), Thiongo (1986), Kebede (2005), and Dugassa (2011) have persistently put their finger on mind colonisation as a veritable incubus, with which Africans have to come to terms and for which they have to find a decolonising solution once and for all. This burden seems to be at the root of many internal factors that unconsciously nourish coloniality. In other words, if Africans have to minimise the impact of global coloniality, decolonising the mind lies at the core of the struggle for an alternative future. But how is mind decolonisation achieved?

In this article, I shall use the Exodus wilderness wanderings metaphor as a theo-decolonial frame for mind colonisation. I shall explore how "postcolonial neo-colonial"-marked African Christianity ${ }^{4}$ can draw resources from the wilderness wanderings paradigm, in order to engage in the process of liberating freedom through mind decolonisation. I shall raise the following questions: Why were the wilderness wanderings so significant for the newly liberated Hebrew community in Exodus? What are the implications of the wilderness wanderings for many African Christians struggling with mind colonisation? In what ways can they interpret their contemporary

3 Ndlovu-Gatsheni (2013a; 2013b; 2013c) has popularised this paradigm in his numerous works.

4 In this article, I differentiate between the notions "Christianity in Africa" and "African Christianity". The latter refers to Christianity's impact in Africa and its geographical location. The fact that something exists in Africa does not qualify as African. In other words, because Christianity exists in Africa, this does not make it African, since even those churches that express their Christianity in traditional Western form in their theologies and expressions also exist in Africa, but their spirituality is not African, because it does not represent the authenticity and originality of African spirituality. The second to which this article refers, "means the original, not counterfeit or copied, a bona fide, an unquestionable or authentically belonging, shaped from African traditional wisdom and philosophy" (Maluleke 2010:373). 
"postcolonial neo-colonial" experiences in light of the wilderness wanderings? In responding to some of these towering questions, I shall show how African Christianity can deploy African religious-cultural resources in dialogue with a global cultural constellation in order to construct a theoliminal pedagogy for mind decolonisation.

\section{THINKING OUTSIDE THE COLONIAL BOX: A THEO-DECOLONIAL TURN}

Despite the immense blessings of natural wealth, many African nations are inescapably marked by misery, material distress, deprivation, disease, and chaos. In the aftermath of geopolitical decolonisation, the hope for an imagined postcolonial African society was dashed into the abyss of neo-colonialism "as a problematic terrain of emptiness, illusions, myths and shadows of being free and decolonised" (Ndlovu-Gatsheni 2013a:13). Through their painful struggle for liberation, African nations became independent. However, this exuberance was momentary, as each nation rapidly fell into the hands of another enemy: "postcolonial neo-colonialism". They have become victims of liberation. The loss of freedom before it was even fully realised is not unique to Africa. The Hebrews in the Exodus left Egypt with exuberance, but their hopes were also dashed as they began to experience the barrenness and harshness of the wilderness. In Egypt, they were desperate for freedom, but shortly after they left, it became clear that geopolitical freedom was illusive without the liberation of their minds. The Hebrews believed that, once they leave the physical bondage of Egypt, they would be liberated. In fact, the slavery that seemed external re-emerged as the Hebrews" own consciousness and the wilderness wanderings became a pedagogy of struggle to reclaim their subjectivity and agency (Bernstein 1998). In this way, the wilderness experience was a "post-physical bondage" decolonial conceptual tool for decolonising the Hebrew mind.

Therefore, theo-decoloniality, as African theological paradigm, is a struggle to unmask the manifestation of Africa's own self-recolonising thought system disguised as the legitimate way of knowing, acting and knowledge production in Africa - an uncontested way of meaning-making and interpretation of reality. It challenges the dominant assumption that Euro-American is the only epistemic site from which Africans should define, describe, conceptualise, and rank themselves (Ndlovu-Gatsheni 2013b:25). It calls for a theological knowledge that redefines and re-describes the reality from "the cosmologies and epistemologies of the subalterns" (Ndlovu-Gatsheni 2013b:25). The subalterns are people located on the 
margins or the oppressed and exploited side of "postcolonial neo-colonial" difference (Grosfoguel 2011). Theo-decolonial thought inaugurates a new thinking about theological strategies and tactics for mind decolonisation in Africa. It

is "an-other thought" that seeks to inaugurate "an-other logic", "another language", and "an-other thinking" that has the potential to liberate ex-colonized

people's minds from the colonial, neo-colonial, self-recolonising thought system (Mignolo, cited in Ndlovu-Gatsheni 2013:7). The theo-decolonial

turn is the opening and the freedom from the thinking and the forms of living (economies-other, political theories-other), the cleansing of the coloniality of being and of knowledge; the de-linking from the spell of the rhetoric of modernity, from its imperial imaginary articulated in the rhetoric of democracy (Mignolo 2011:48, original italics).

It is about uncovering the colonial mentality that African people reproduce in their interpretation of realities. It resists such distorted realities, formed from a corrupted psyche by colonialism, that undermine every attempt for Africa to forge a distinctive destiny apart from the Western world. It transgresses the dominant ideology that enthrones Euro-Americans as the crown of humanity, and relegates African people to the bottom of humanity as the damnes (damned or wretched of the earth).

The approach argues that the process of geopolitical decolonisation was blind to the fact that colonialism was more than physical; it was an alienation of the African subject from the "original self" that led to the loss of familiarity with the self and the estrangement from the ontological realities "relegating them to objecthood and nothingness" (Mbembe 2002:24; cf. also Ndlovu-Gatsheni 2013b:102). According to this perspective, mind colonisation is a key constraint in African socio-political progress and economic development. It is a site of struggle for authentic African humanity. During colonialism, African people internalised oppression, lost sight of indigenous agency, and have continued to recolonise themselves (Asante 1990). Therefore, the theo-decolonial paradigm addresses a theological question as to how mind colonialism repressed African Christian modes of knowing, religious meaning-making, social imagination, seeing and theological construction, and substitute them with theologies of development engendered by an alienated mind. The colonised mind is preoccupied with theories of "catching-up" with Western progress, rather than invest in seeking contextualised sustainable paradigms of development and allowing the continent to develop at its own speed. This does not mean that the approach subscribes to a monolithic uniformity 
view of African cultures. On the contrary, it holds that these cultures are constantly changing and adapting, appropriating and assimilating other global cultures without losing distinctiveness. The theo-decolonial thinking is aimed at developing strategies and tactics for creating a new thought system and constructing new subjectivities by reclaiming and reconstituting the African cultural heritage in its modern manifestation, resulting in the new modes of being and becoming human as a Christian. In the next section, I shall engage mind colonialism in light of the Exodus wilderness wanderings. How can we understand contemporary African struggle in light of the Exodus wilderness wanderings narrative?

\section{READING THE AFRICAN EXPERIENCE IN LIGHT OF THE WILDERNESS WANDERINGS}

The Exodus narrative has captivated the minds of numerous liberation theorists and theologians worldwide (Ela 1986, 1991; Lunn 2014; Lee 2010; Moon 1991; Pixley \& Boff 1991; Warrior 1991; Brueggemann 1995). It has been used as a paradigm

for modern revolutions and liberations, national and social, where the saving remnant hopes to wipe out oppression and corruption, depart physically or politically from their oppressors and corruptors, and remake their society (Waskow 1991/1990:516).

Mugambi (1995:165) notes that

metaphorically, African people have been likened to the people of Israel on their way from the land of bondage in Egypt to the Promised Land in Canaan.

He himself feels dissatisfied with the motif and believes that, in postcolonial neo-colonial Africa, it is "totally inapplicable and irrelevant" (Mugambi 1995:165). Mugambi and other Africanists, who have appealed to this motif, have not yet raised the following questions: Have African Christians correctly used the Exodus motif in the African quest for liberation independence? What have they missed in their utilisation of the Exodus motif? What is the role of the Exodus experience in enabling the Hebrew people to liberate themselves from the Egyptian ideological bondage? It is unfortunate that, although the Exodus pattern has been such a powerful motif for the African quest for liberation colonialism, it has not been perceived to have sufficient power for an African liberation from colonial ideological bondage. Many Africanists have hardly paid any attention to the critical events that unfolded between Egypt and the Promised Land. 
They have failed to pay sufficient attention to the fact that the Exodus struggle was not only about struggling to liberate Hebrews from Egypt, but a narrative of struggle to liberate an Egypt-entrenched Hebrew mind.

Thus, they try to differentiate between Hebrew de-enslavement and African decolonisation based on the argument that

the Israelites move[d] physically over time and space, from Egypt across the Sinai to Canaan, whereas African[s] remain in the same geographical space. Thus the Exodus, when transposed to the African situation, is over time, without any geographical movement (Mugambi 1995:14-15).

Such arguments are based on a literal reading of Exodus, and have failed to view that the Exodus movement could be a metaphor that can be transposed into equivalent cultural idioms such as liminal spaces, which have to do with movement from social structural geo-socio-political space into anti-structural geo-socio-political space. In this way, the Exodus journey reflects the fact that geographical movement had nothing to do with mind decolonisation, as Israelites while having left Egypt physically still relied on Egypt as their point of reference for self-definition and reality interpretation; hence, they remained mentally captive to Egyptian ideology. Therefore, it was not so much about geographical movement as much as mind decolonisation that could only happen in the liminal space. Exodus embodies a quest for freedom, a movement, or progression from a geosocio-political structure into a liminal space of mind transformation that opens new possibilities for entering into liberated geo-socio-political and economic realities.

A Jewish Rabbi, Yosef Jacobson (s.a.) notes that a superficial reading of the wilderness account would conclude that God was simply punishing the people whom he had liberated. But, the wilderness narrative struggles with the question as to how to transform ex-slaves into free-minded people (Bernstein 1998:53). The process of mental liberation is the hardest and worst part of slavery/colonialism. There is no such thing as dramatic change.

Thus, the wilderness experience for the Jewish people, as Bernstein, a Jewish scholar, argues,

was not a vocation; it was an occupation. It was a necessary initiation rite - part of the making of a Jew (1998:53).

The American Jewish author and rabbi, Chaim Potok (1980:81), argued that one of the earliest names of the Jewish people, hapiru (Apiru), derived from a Semitic phrase, possibly Habiru, meaning "wanderer". Jewish scholars 
make the point that the Hebrew people wandered in order to reclaim their Jewishness and Yahweh-centred thought system. It was an essential component in the recovery and reconstitution of a Jewish identity and agency (Hirsch 1988; Bernstein 1998:53). In this way, the wilderness wanderings could be considered a kind of decolonial process after liberation from Egyptian slavery. These scholars demonstrate how the wilderness experience, as a process of liberating the Hebrew mind from Egyptian corruption, was fundamental in the formation of radically segregated individuals into a liberated interdependent Jewish nation.

Bernstein observes that Mount Sinai, where the Hebrew received the law, was merely a two-month journey from Egypt. She argues that, upon reaching Sinai, the Hebrews should have been able to proceed this short distance into the Promised Land and settle. But, they were promised to be a liberated community, a free people, and the Hebrew people who left Egypt were not free; they were still in bondage. Although they had left Egypt, they carried Egypt in their minds in the form of perceptions, selfdefinitions, self-reference, and conception of realities - "deep inside them" (Bernstein 1998:53). For Jacobson (s.a.), "the slave mentality had become too deeply ingrained in their psyches". Thus, it

took 40 years of traversing back and forth across the same wilderness for them to become free: to take responsibility for their own destiny, to believe in themselves, and to dream again (Bernstein 1998:53).

As observed earlier, they should have entered the Promised Land almost immediately after liberation from Egypt, but they were not mentally ready to face the challenges of nation-building and did not have the intellectual tools for socio-political and economic development. Yahweh's option to wander in the wilderness rather than to take them straight into the Promised Land is articulated in Exodus 13:17. Yahweh opined that the people would change their minds if they faced the difficult challenges of progress along the way. Not only did they lack the critical skills in public participation, public administration, public management and sociopolitical governance, but their capacity to think authentically was distorted and corrupted by 400 years of thought deprivation. This is similar to the pervasive mind colonialism in many African countries. It manifests in the way in which nations are governed, in the mechanisms of economics, in the ferocious struggle for power, in the failure to prioritise health care, in pews of society, in knowledge production, in education systems, and in curricula. For instance, the Ebola epidemic in West Africa has exposed the failure of many African nations to prioritise the development of health-care infrastructure. 
In addition, the Hebrews had a wrong notion of liberation. For them, liberation meant doing nothing, but enjoying everything on a silver platter. The responsibility that defines liberation was not part of their notions of liberation. The Israelites said,

If only we had died by the Lord's hand in Egypt! There we sat around pots of meat and ate all the food we wanted, but you have brought us out into this desert to starve this entire assembly to death (Exodus 16:2-4).

Similar to the period of colonialism in Africa, although slavery limited the freedom of the Hebrews, it nevertheless provided the necessities of life. This limited agency functioned through mentally and conceptually corrupted systems of thought. This enslavement of the mind manifested throughout their journey in the wilderness. Whenever they encountered a crisis, they wanted "to go" back to Egypt (cf. Exodus, Chapters 13-17; Numbers, Chapters 11-14). God vowed that the old generation that left Egypt would die in the wilderness, and that only their children would receive the gift of the land after forty years (Numbers 14:26-33). In contemporary Africa, the death of the old generation of Hebrews in the wilderness should not be taken literally, but as a metaphor signifying liberation from mind colonisation. Only after the death of old-colonised-selves will African Christians become adequately prepared to contribute to the development of their particular nations.

Similarly, economic challenges and socio-political failures in Africa are blamed on colonialism (Mapuva \& Freeman 2010). The theories of underdevelopment are inextricably linked with colonialism. Even when many Africans are aware that some African leaders do not seem to have the emotional and intellectual capacity to take on the challenges of economic development, the majority still support them. As a result, these leaders retreat behind self-imposed ghetto walls and take on assimilation perspectives to Western imposed notions of democracy. Another manifestation of mind colonialism among African leaders is their inability to take responsibility for the destinies of their nation rather than making excuses and blaming history. Moses himself only became a liberationist and a leader after experiencing mind decolonisation as a fugitive in Median where he spent forty years as a shepherd (Exodus 2:15). Could this suggest that only a decolonised mind is sufficiently prepared to lead the nation into successful and sustainable political and economic development?

The Hebrew people came out of Egypt as a group of ex-slaves; they were not an interdependent community or a nation, but a group of people who were estranged, segregated and alienated from one another. This is how African people emerged from colonialism. They may have 
remembered certain cultural aspects, but during colonialism many of them were abandoned, as they did not have the absolute freedom to adequately express themselves. Colonial Christianity destroyed many critical elements of the African cultural heritage. For instance, the traditional wisdom and philosophy of Ubuntu, which is so popularised in South Africa, is so distorted that its meaning is illusive. In fact, Ubuntu is rather an academic jargon with hardly any or no practical consequence for the community.

For the Hebrews, the wilderness wanderings became central in the process of turning the ex-slaves into "a kingdom of priests and a holy [distinctive] nation" (Exodus 19:6) by coming to terms with who they are as Jewish people. The ex-slaves were not in a position to govern themselves. In his novel, Maimonides (1904) suggests that the Jews were mentally, psychologically, and emotionally unequipped to conquer the land. The long period of oppression, slavery and suffering under the brutal Egyptians deprived them of the courage and confidence required to deal with the socio-political and economic challenges. They possessed neither the dignity nor the self-assurance necessary for nation-building.

Therefore, Israel's wilderness experience can be taken as an example of reality-creating pedagogy. The forty years of wilderness wanderings was a process of re-learning, not simply to be human together, but to interpret Israel's realities within the Hebrew model of a Yahwistic-centred system of thought and wisdom. The wilderness wanderings show that the Hebrew mind emancipation occurred in the liminal space between Egypt and the Promised Land; between the old and the new; between what they were as slaves and what they would become as a free nation. It was a rite of passage, an essential agonising process of mind de-enslaving. The Psalmist records that for forty years Israel went through the school of mind liberation from Egyptian mentality. Without undergoing this radical process, the Hebrews would have been unable to forge a distinctive nation (Ps. 95:10). The wilderness learning of Israel was their strategy to break free from interpreting Egyptian realities as their own, thereby re-enslaving themselves long after the physical liberation. This process compelled them to reclaim their Yahwistic-centred ways of thinking and acting. Through this paradigm of thinking, the Hebrew people could begin to construct distinctive knowledge known as the "Torah", which has implications for ordering their lives in contrast to the Egyptian way of life.

From the foregoing discussion, a number of lessons can be drawn in terms of the metaphor of the wilderness wanderings. First, the wilderness wanderings is a profound metaphor for the process of mind decolonisation for any group of people who have experienced a long period of oppression, slavery or colonialism, as they would need to rediscover who they are and 
where they belong, as well as relearn how to live in a community with each other (Bernstein 1998:56). It appears that this learning process even applies in the context of the rehabilitation of prisoners. It is a process that many ex-colonised African nations seem to have missed. Hence, the seemingly perpetual struggle.

Secondly, the process was a necessary opportunity for the Jewish people to perceive their slavery for what it was, to purge their minds of its entrenchment, to reclaim a vision for their future, to communally own the process of social formation and coherence, to become proactive, and to re-establish and develop community intimacy and bonding with each other and the land so that they can all fully participate in the process of nationbuilding. It was a process of moving from an imagined nation to a realised nation. If this observation were true, one could argue that mind colonialism may be the source of Africa's limitations, uncertainties, and pathological underdevelopment. It seems to have severed the African rhythm of progress by alienating many Africans from their past, masking their potential for the future, and depriving them of their immeasurable power to transform their situation and become masters of their destiny. The question is: Is it too late for African people to deliberately, decisively, consciously, and courageously embark on the process of wilderness wanderings? If it is not, how can they possibly achieve that?

Thirdly, the necessity of the wilderness wanderings process was to reclaim, recover, and reconstitute Yahwistic-centred thought and wisdom. Egyptian slavery corrupted this distinctive Jewish mode of thinking, way of knowing or meaning-making and being in the world. The people were made in the image of the Egyptians and there was no way in which they would go beyond Egyptian ways of knowing and conceptualising reality. Therefore, the wilderness wanderings was a process of re-educating themselves into the Hebrew cognitive. God is not the main actor in the process, but the people themselves played a conscious role in reclaiming their identity and agency. There was a greater possibility that without deenslaving their minds, the Hebrew people would have continued to reenslave themselves with dire consequences in terms of human progress as well as socio-political and economic development. Reclaiming Yahwisticcentred thought was essential for them in order to sustain their freedom in the Promised Land.

Similarly, if many Africans were to move past the ideology of blaming colonialism and imperialism, they would have to reclaim their materialityspirituality-centred thought and wisdom. Yet, Africans must not simply achieve this by completely abandoning Western categories of thought. The goal must be radical reconciliation of African thought with the Western 
scientific thought system. If there is anything crucial to reclaim, it is the African indivisible thought that attempted to maintain a critical balance of ways of knowing and being in the world. Africans cannot possibly "destroy these [Western thought system] institutions and build their own" (NdlovuGatsheni 2013a:186). In an integrated global community, knowledge must be reconciled, rather than to create ghetto walls around knowledge that is simply self-limiting and self-alienating. In the next section, I shall begin to formulate some contours for such a theo-liminal pedagogy, with the theoretical foundations of the wilderness wanderings.

\section{THEO-LIMINAL PEDAGOGY: BETWEEN EGYPT AND THE PROMISED LAND}

The underlying struggle of the contemporary African continent is the struggle for mind decolonisation. African scholars have found it difficult to suggest an adequate frame of learning that can facilitate and empower African people to reclaim, restore, and reconstitute their traditional system of thought and wisdom. The problem is to construct a pedagogy that can manage to selectively integrate some progressive elements of African traditional thought (recognising the fluidity and dynamism of cultural traditions) and critical aspects of the Western system of thought. This is a system of thought that endeavours to find an intricate balance (margin) between these thought systems without falling prey to either of them. I call this paradigm theo-liminal pedagogy, in which "the intellectual, cultural and ideological spaces" (Conroy 2004:7-8) exist on the margins of African traditional and Western thoughts. It is neither at the centre nor on the boundaries, but it moves to and fro between the two paradigms. Early anthropologists in Africa such as Victor Turner have helped us understand that, in many African societies, the liminal spaces, where traditional marginal spaces are sites for negotiating between the physical and the spiritual, were used as critical pedagogies. ${ }^{5}$ It has been clarified that the current postcolonial metaphorical use of liminal space can be traced back to precolonial cultural discourses. Bhabha (1994:4) explains that the

liminal space, in-between the designations of identity, becomes the process of symbolic interaction, the connective tissue that constructs the difference between upper and lower, [African and Western] ... the temporal movement and passage that it allows, prevents identities at either end of it from settling into primordial polarities. The interstitial passage between fixed identifications opens up the possibility of a

5 For a detailed discussion, cf. Turner (1974; 1967; 1969). 
cultural hybridity that entertains difference without an assumed or imposed hierarchy.

The theo-liminal pedagogy moves to and fro in an "interstitial passage" between the realms of humanity, nature and spiritual dimensions, where traditional and modern; the known and the unknown; materiality and spirituality; science and faith tentatively converge. This is the liminal space with its roots in the metaphysics of African traditional cultural heritage (Whittaker 2001). Theo-liminal thought echoes the wilderness wanderings motif, which was a negotiation between Egypt and traditional Hebrew thought systems. Theo-liminal pedagogy suggests a radical movement from normative socio-political structures to subversive anti-structural dimensions. It seems to have the potential to inform an Africanised theodecolonial paradigm that can "privilege epistemologies, pedagogies, and curriculum that are consonant with specific African historical, cultural and practical realities" (Ndlovu-Gatsheni 2013a:180). The question is: How would this kind of Africanised approach function in an interdependent and integrated global society? I do not claim to fully understand the nature of such an approach and how it would function. The following figure illustrates the possible interaction in theo-liminal pedagogy for mind decolonisation in an African Christian.

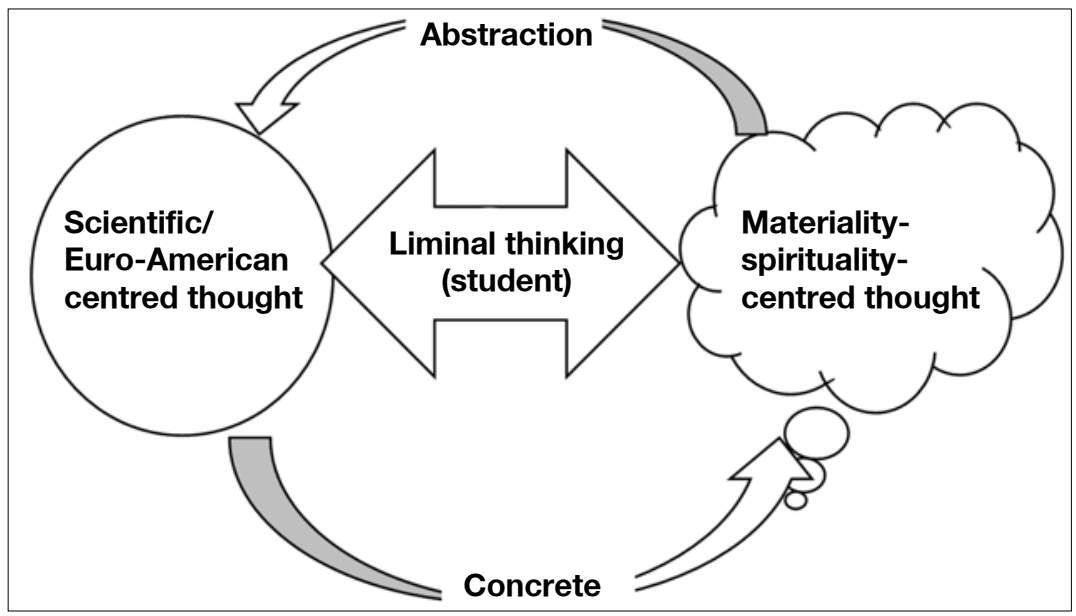

In this figure, the liminal space is situated between scientific/Euro-American centred and African materiality-spirituality thought systems. I call the African thought system materiality-spirituality in order to remain faithful to African metaphysics, which functioned in an indivisibility or inseparability 
of materiality and spirituality. This thought system functioned between materiality and spirituality - something neither physical nor spiritual. It situated the students in the liminal space as inexplicable exchanges between mystical and rational dimensions of reality in terms of values, beliefs, and ideas of integrity and dignity shaping both individual and collective consciousness into a unified existence (Dei 2002:4). It was an in-between consciousness that echoes Rahnema's (1992:130) definition of spirituality as

\begin{abstract}
sensitivity, the art of listening to the world at large and within one, from the hegemony of conditioned "me" constantly interfering in the process; the ability to relate to others and act, without any pre-defined plan or ulterior motives, and the perennial qualities of love, compassion and goodness which are under constant threat in economized societies.
\end{abstract}

In contrast with contemporary education, which focuses mainly on acquiring academic skills (scientific classroom) with hardly any or no attention to the ways in which students should engage with the community and the natural world, traditional methods of learning were based on critical negotiation between spirituality and materiality, and between abstract and concrete.

\title{
5. CONCLUSION
}

To conclude, the purpose of this article was to chart new directions for initiating a discussion on the way forward in decolonising the African mind and subjectivity. This short article could not possibly deal with all the issues. I argued that the wilderness wanderings teach that liberated freedom does not follow geopolitical liberation, but only when personal and communal subjectivity has been reclaimed, recovered, and reconstituted. In other words, mind decolonisation should be understood in holistic terms. Recovery from mind colonisation constitutes the first step towards economic and political development, social cohesion, and nation-building. Recovery from mind colonialism is an enormous and hazardous task, but inevitable if African Christianity is to contribute adequately to the process of poverty eradication, social transformation, political and economic progress, and so on.

\section{BIBLIOGRAPHY}

\section{ACHEBE, C.}

1985. The trouble with Nigeria. Enugu: Fourth Dimension Publishing.

AsANTE, M.K.

1990. Kemet, Afrocentricity and knowledge. Trenton: Africa World Press. 
AYITTEY, G.B.N.

1992. Africa betrayed. New York: St. Martin's Press.

1998. Africa in chaos. New York: St. Martin's Press.

2002. Why Africa is poor. In: J. Morris (ed.), Sustainable development: Promoting progress or perpetuating poverty? (London: Profile Books), pp. 57-75.

BAKER, D.G.

1975. Politics, power and race relations. In: D.G. Baker (ed.), Politics of race: A comparative study (Westmead: Saxon), pp. 1-22.

Bernstein, E. 1998. Ecology and the Jewish Spirit: Where nature and the sacred meet. Woodstock: Jewish Lights Publishing.

BНАBHA, H.K.

1994. The location of culture. London: Routledge.

Brueggemann, W.

1995. Pharaoh as vassal: A study of a political metaphor. Catholic Biblical Quarterly 57(1):27-51.

Conroy, J.C.

2004. Betwixt and between: The liminal imagination, education and democracy. New York: Peter Lang.

DEI, G.J.S.

2002. Spiritual knowing and transformative learning. NALL Working Paper, 59:1-13. [Online.] Retrieved from: http://nall.oise.utoronto.ca [2014, 1 October].

DugASSA, B.F.

2011. Colonialism of mind: Deterrent of social transformation: The experiences of Oromo people in Ethiopia. Sociology Mind 1(2):55-64. http://dx.doi.org/10.4236/ sm.2011.12007

ELA, J.-M.

1986. Africa cry. Maryknoll, NY: Orbis Books.

1991. A Black African perspective: An African reading of the Exodus. In: R.S. Sugirtharajah (ed.), Voices from the margin: Interpreting the Bible in the third world (Maryknoll, NY: Orbis Books), pp. 244-245.

FANON, F.

1952. Black skin, white masks. Translated by C.L. Markmann. New York: Grove Weidenfeld.

1961. The wretched of the earth. Translated by R. Philcox. New York: Grove Weidenfeld. 
Grosfoguel, R.

2011. Decolonizing post-colonial studies and paradigms of political-economy: Transmodernity, decolonial thinking, and global coloniality. Transmodernity 1(1):1-37.

GYEKYE, K.

1987. An essay on African philosophical thought. London: Cambridge University Press.

HIRSCH, S.R.

1988. The Hirsch Haggadah. New York: Philipp Feldheim.

JACOBSON, Y.Y.

s.a. Judaism: The slave mentality and withdrawal. [Online.] Retrieved from: http://www.israelnationalnews.com [2014, 26 November].

Kebede, M.

2005. African development and the primacy of mental decolonisation. Philosophy and African Development: Theory and Practice 29(1). [Online.] Retrieved from: http://www.codesria.org/IMG/pdf/6-3.pdf [2013, 25 October].

LeE, B.

2010. Toward liberating interdependence: Exploring an intercultural pedagogy. Religious Education: The Official Journal of the Religious Education Association 105(3):283-298. http://dx.doi.org/10.1080/00344081003772055

LunN, N.P.

2014. "Let my people go!" The exodus as Israel's metaphorical divorce from Egypt. EQ 86(3):239-251.

MAIMONIDES, M.

1904. The guide for the perplexed. Translated from the original Arabic text by M. Friedlander. $2^{\text {nd }}$ edition. London: Routledge \& Kegan Paul.

Maluleke, T.S.

2010. Of Africanized bees and Africanized churches: Ten theses on African Christianity. Missionalia 38(3):369-379.

Mapuva, J. \& Freeman C.

2010. Colonialism no longer an excuse for Africa's failure. Journal of Sustainable Development in Africa 12(5):22-36.

Mazrui, A.A.

1986. The Africans: A triple heritage. London: BBC Publications.

Мвемве, A.

2002. African modes of self-writing. Translated by S. Rendall. Public Culture 14(1):239-273. http://dx.doi.org/10.1215/08992363-14-1-239

MIGNOLO, W.D.

2005. The idea of Latin America. Malden, MA: Blackwell Publishing. 
2011. Epistemic disobedience and the colonial option: A manifesto. Transmodernity 1(2):44-66.

Moon, C.H.S.

1991. A Korean Minjung perspective: The Hebrews and the Exodus. In: R.S. Sugirtharajah (ed.), Voices from the margin: Interpreting the Bible in the third world (Maryknoll, NY: Orbis Books), pp. 228-243.

MugamBI, J.N.K.

1995. From liberation to reconstruction: African Christian theology after the Cold War. Nairobi: East Africa Educational Publishers.

Ndlovu-Gatsheni, S.J.

2011. The logic of violence in Africa. Ferguson Centre for African and Asian Studies Working Paper No. 2 (Open University). [Online.] Retrieved from: www. open.ac.uk/Arts/ferguson-centre/working-papers [2014, 27 November].

2012. Beyond the equator there are no sins: Coloniality and violence in Africa. Journal of Developing Societies 28:419-440. http://dx.doi.org/10.1177/ $0169796 \mathrm{X} 12463143$

2013a. Coloniality of power in postcolonial Africa: Myths of decolonization. Dakar: CODESRIA.

2013b. Empire, global coloniality and African subjectivity. New York: Berghahn Books.

2013c. Perhaps decoloniality is the answer? Critical reflections on development from a decolonial epistemic perspective. Africanus: Journal of Development Studies 43(2):1-12.

PHIRI, I.A.

1997. Women, Presbyterianism and patriarchy: Religious experience of Chewa women in Central Malawi. Blantyre: CLAIM.

Pixley, G.V. \& Clodovis, B.

1991. A Latin American perspective: The option for the poor in the Old Testament. In: R.S. Sugirtharajah (ed.), Voices from the margin: Interpreting the Bible in the third world (Maryknoll, NY: Orbis Books), pp. 215-217.

Pobee, J.S.

1979. Towards an African theology. Nashville, TN: The Parthenon Press.

Роток, C.

1980. Wanderings. New York: Fawcett Crest.

Rahnema, M.

1992. Participation. In: W. Sachs (ed.), Development dictionary: $A$ guide to knowledge as power (London: Zed Books), pp. 116-131. 
TURNER, V.

1967. The forest of symbols: Aspects of Ndembu ritual. Ithaca, NY: Cornell University Press.

1969. The ritual process: Structure and anti-structure. Ithaca, NY: Cornell University Press.

1974. Dramas, fields and metaphors: Symbolic action in human society. Ithaca, NY: Cornell University Press.

WA THIONGO, N.

1986. Decolonising the mind: The politics of language in African literature. Oxford: James Curry.

WARRIOR, R.A.

1991. A Native American perspective: Canaanites, cowboys, and Indians. In: R.S. Sugirtharajah (ed.), Voices from the margin: Interpreting the Bible in the third world (Maryknoll, NY: Orbis Books), pp. 277-285.

Waskow, A.

1990/1991. Exodus is not enough. Cross Currents, 40(4). [Online.] Retrieved from: http://web.b.ebscohost.com [2014, 27 November).

WHITTAKER, D.

2001. Realms of liminality: The mythic topography of Amos Tutuola's Bush of Ghosts. SOAS Literary Review 3:1-18.

Keywords

The wilderness wanderings

Decoloniality

Theo-liminal pedagogy

African Christianity
Trefwoorde

Die wildernesreise

Dekolonialiteit

Teo-liminale pedagogie

Afrika Christendom 